\title{
CHOSEN ASPECTS OF PROJECTS REALIZATION AT CHINESE UNIVERSITIES ON THE EXAMPLE OF HUAZHONG UNIVERSITY OF SCIENCE AND TECHNOLOGY (HUST)
}

Project management is the basis for the development of various organizations in a changing environment at present time. This method is very popular in developed European countries and has developed in Poland for the last 10 years. In other developed countries projects are also coming to be a very important part of the economy. This situation can be observed among others in China.

The aim of the paper is to analyze the Chinese universities in the context of system project management and to compare their approach with the most popular methodologies in European countries. Currently, China stands out in the world in terms of reforms in the area of both higher education and innovation systems. The size of investments and the economic effects achieved, allocate this country in the top in the world in this area. Therefore, it is very important to analyze and understand processes in this country.

Chinese universities often provide a very big projects due to the size of the state and the amount of population. Analyzing the situation on the basis of Huazhong University of Science and Technology (HUST the usage of project management methods similar to the European Union) could be seen. There are also differences resulting from the culture of project management.

The article is based on studies and information gathered from Chinese universities, especially HUST. Knowledge and information acquired made it possible to describe the role of projects in investigated university and generally compare.

Keywords: project management, China, Chinese universities, university.

\section{INTRODUCTION}

At present, companies as well as other organizations strive to maximize effectiveness and efficiency. It requires the permanent development in both areas - inside the organization and in relation to markets. There are many management methods that help to improve the way of activity in the mentioned dimensions. One of them is the project

\footnotetext{
${ }^{1}$ Grzegorz Przewoźnik, Student's Scientific Association „Eco-business”, Faculty of Management, Rzeszow University of Technology, ul. Powstańców Warszawy 12, grzegorz.przewoznik1@ gmail.com

${ }^{2}$ Hanghang Lan, International Student Office, Huazhong University of Science and Technology (HUST), Wuhan, China, lanhanghang@hust.edu.cn

${ }^{3}$ J. Strojny, PhD, Department of Economics, Rzeszow University of Technology, Rzeszow, Powstańców Warszawy 12, jstrojny@prz.edu.pl (corresponding author)
} 
management ${ }^{4}$. In present economy projects are a very important part and can be identified in all over the world in many companies, institutions, non-profit organizations and universities as well ${ }^{5}$. The project management is an approach which can help the organizations in various activities in the market and retain or rise the competitive position ${ }^{6}$. Different methodologies of project management define methods, procedures or activities needed to ensure that everything goes ahead with maintaining profitability ${ }^{7}$. Managing the project is a process which includes the project defining, planning, controlling and evaluating ${ }^{8}$. The efficiency of this process depends on the appropriate design of the organization, organizational culture and many other factors. They are described in models of project oriented organization ${ }^{9}$. The success of the project means that it has been completed in accordance with the specifications and requirements.

The main goal of this paper is to present basic characteristic of Chinese universities in the context of projects realization. As the example the Huazhong University of Science and Technology was chosen. The observations achieved at this university could be helpful to understand the specific character of China and its economy. Chinese universities are coming to be an important part of the global educational market ${ }^{10}$. The level of higher education and innovative effects of scientific and development researches indicate that they are more and more significant partners for European universities. This opportunity should be also taken into consideration at Polish universities.

Projects provided at universities are used to deliver the high amount of knowledge to the economy of the country ${ }^{11}$. The university must adapt knowledge to the prevailing conditions, and therefore must be able to identify, prepare and provide projects also in areas important for the environment ${ }^{12}$. This means that in many cases, universities create a multiproject background, very often in cooperation with other organizations (e.g. companies). It forces them to use different processes of control and coordinate a number of projects at the same time (projects portfolio management). Very important here are aspects of the analysis of stakeholders expectations, such as resource allocation, costs, products and services delivered, etc. In both, China and Europe project should be analyzed also taking into consideration local, regional and national specializations of systems of innovations ${ }^{13}$.

${ }^{4}$ J. Strojny, Zarządzanie projektami innowacyjnymi, Rzeszów, Politechnika Rzeszowska, 2012.

${ }^{5}$ PRINCE2 - Skuteczne Zarzadzanie Projektami, 2009, AXELOS.

${ }^{6}$ E. Fuessinger, Maturities of Project-Oriented Companies of About 15 Project-Oriented Nations, 2006 [online] Avaliable at: <http:// www.icoste.org/Slovenia2006Papers/icecFinal00100.pdf> [Accessed 26 July 2015], A.K. Munns, B.F. Bjeirmi, The role of project management in achieving project success, International Journal of Project Management, 14(2), 1996, pp. 81-871

${ }^{7}$ J. Charvat Project Management Methodologies, NJ, 20031

${ }^{8}$ J. Wiley \& Sons Ltd, Chichester Project Management: Planning and Control Techniques Rory Burke Third Edition, , England, 1999.

${ }^{9}$ e.g. R. Gareis, Happy Projects!, Manz, Vienna 2005; L. Lianyinga, H. Jinga, Z. Xinxinga, The Project Management Maturity Model and Application Based on PRINCE2, Procedia Engineering, 29, 2012, p. 36913697, E.S. Andersen, S.A. Jessen, Project maturity in organisations, International Journal of Project Management, 21.6, 2003, 457-461, H. Kerzner, Using the project management maturity model: strategic planning for project management, John Wiley \& Sons, Ohio 2011.

${ }^{10}$ R. Hayhoe, China's Universities and the Open Door. Armonk, N.Y.: M.E. Sharpe, 1989. xii, p. 249

${ }^{11}$ Ibidem, p. 2.

${ }^{12} \mathrm{http}: / /$ english.hust.edu.cn/about_Facts.html

${ }^{13}$ J. Binder, Global Project Management: Communication, Collaboration and Management across Borders, Emerald Group Publishing Limited. 
This article attempts to analyze the systemic project management in the field of higher education in China. The study was based on one of the best universities in China: Huazhong University of Science and Technology (HUST). It is worth pointing out that every year a high number of projects are implemented by this university. An important aspect is the unification of the way of managing projects. In order to control the projects, the university needs a systemic approach to many areas of management: financial, risk, resource, quality and even documentation. The comprehensive approach to project management constitutes and identifies scopes that must be taken into account at the university in order to obtain the expected results.

\section{TYPES OF PROJECTS AT UNIVERSITIES REFERING TO THE SITUATION IN CHINA}

It is worth mentioning that currently most of the universities, also in China implement various types of projects. They can be separated into two groups: 1) soft educational and research (soft projects) and 2) investments in infrastructure (hard development project). Some projects have, of course, both mentioned above components - soft and hard. What is more, projects at universities are realized within the big national undertakings, which fulfill the conditions of definition of program ${ }^{14}$. That is why a lot of projects are provided by Chinese universities, but they are also coordinated by the government (appropriate ministry).

In the group of educational projects, among others, Project 211 and Project 985 can be selected. They are the two huge national projects in the higher education field up to now and projected universities receive huge funds besides the basic governmental investment for development each project period. 211 is a project of National Key Universities and colleges initiated in 1995 by the Ministry of Education of the People's Republic of China, with the intent of raising the research standards of high-level universities and cultivating strategies for socioeconomic development. China today has 116 institutions of higher education (about 6 percent) designated as 211 Project institutions for having met certain scientific, technical, and human resources standards and offer advanced degree programs). Project 211 schools take on the responsibility of training four-fifths of doctoral students, two-thirds of graduate students, half of students from abroad and one-third of undergraduates. They offer $85 \%$ of the state's key subjects, hold 96 percent of the state's key laboratories, and utilize $70 \%$ of scientific research funding.

Project 985 was created by President Jiang Zemin in order to strengthen the position of Chinese universities in the world. The president wanted many Chinese universities to be in the top places. The project involved 39 universities from all over China. The project provides money for key universities in order to improve conditions for education, increasing the number of international conferences, scholarships for people from all over the world, etc. Currently they are very sought after by this kind of institutions because they give them a very high prestige among others. They also allow to achieve real impact on the economy, because of implementation the ideas and new knowledge to real processes in organizations.

In the context of research projects, China has invested a lot in research and the total amount of investment has reached to 41 billion Dollars in 2014. Research programs could

\footnotetext{
${ }^{14}$ Program is a long-term undertaken which include a lot of projects that realize the same strategic goal, source: Office of Government Commerce (OGC), Managing Successful Projects with PRINCE2 ${ }^{T M}$, TSO, London 2009, p. 31 .
} 
be generally separated into the National Natural Science Foundation, National High-tech R\&D Program (863 program), National Key Technologies R\&D Program, National Basic Research Program (973 Program), National Science and Technology Infrastructure Program, Environment Building for S\&T Industries, Mega-projects of Science Research for the Each Five-year Plan. Project 973 was designed to boost strategic technological advantage and also in various areas of science created in 1997 by the Chinese authorities ${ }^{15}$. Taking HUST as one example, the number of 973 projects was completed in 1999, 1 project, 2002 1, 2003 2, 2004 1, 2005 1, 2006 1, 2007 2, 2008 1, 2009 1, 2010 3, 2011 2, 20122 and 20132 projects. Including this program were implemented 20 projects $^{16}$.

Research projects at Chinese universities are often commissioned by local and regional authorities, but mainly by companies; companies R \& D have already covered $76.6 \%$ according to the 2013 China R\&D Report ${ }^{17}$. Providing these undertaken universities cooperate with technological parks. Universities have a very well-designed infrastructure in this area. At some universities, the Chinese government admits the money gradually in subsequent years of implementation of the project. The amount of money each year depends on the work which has to be done $\mathrm{e}^{18}$.

In the category of hard development projects an important aspect for China is a project called the Midwest Higher Education Revitalization Plan. The Chinese government allocated 10 billion RMB ( approximately 6 billion Polish zlotys ) in support of 100 universities in the area of central and western China, in 23 provinces such as, Hubei, Henan and Shanxi. Financial support is intended for development of infrastructure. The main objective is to increase building and the development of research centers in universities. The Midwest Higher Education Revitalization Project is the country's plan to decrease the gap between the levels of development of higher education among different regions.

The plan was adopted due to the fact that $65 \%$ of all universities in China are universities from the western region of the country. Until 2020, according to the plan, universities need to increase the quality and range of activities in all areas, which are set within them. The plan also supports 1000 present universities and colleges in the Midwest regions to have a Capacity Improving Training Program at good universities of the USA, Germany, Britain and Australia in order to bring better ideas for the development of the universities and colleges in the Midwest regions. These activities provide an occasion for more than 185 thousand students from the mid-western region to study in the eastern part of the country. The program focuses on the development of students and thus promotes more domestic exchange study experience at good universities of other regions as well as oversea study chances $^{19}$.

A huge number of projects implemented by universities in China create a big opportunity for students to develop and gain experience. In most of the projects that are carried out by universities, the largest percentage of participants are students. In larger projects, students are divided into different project groups that perform certain parts of the

\footnotetext{
${ }^{15} \mathrm{http}: / /$ www.973.gov.cn/English/Index.aspx

${ }^{16}$ Scientific report Huazhong University of Science and Technology, 2014

${ }^{17} \mathrm{http}: / /$ news.xinhuanet.com/2014-10/23/c_1112948665.htm

${ }^{18} \mathrm{~J}$. Strojny, Kompleksowe podejście do zarzqdzania projektami na przykładzie uczelni wyższej, Wydawnictwo SAN, zeszyt 12, część I, pp. 247-262

${ }^{19} \mathrm{http}: / /$ news.nost.org.cn/2013/06/new-education-plan-10-billion-rmb-investment-in-100-local-universities-in-mi dwest-china/
} 
work. In some moments of project realization these groups meet together within all team. This helps students to understand the operation of each project from the practical point of view $^{20}$. This also allows them to combine theoretical knowledge with experience. The work that students do is checked by professors who are supervisors for phases of projects and managers of projects. The university authorities have a large choice among students because the number of students is huge and not comparable to European universities (e.g. the HUST in HUBEI province where the number of Chinese students exceeds 55 thousand $)^{21}$.

China development through the National Project is enormous. Each university conducts a number of national projects. China wants to develop a system of education at individual universities to raise standards, attractiveness and to allow students to learn in decent conditions. Projects at the national level are implemented in a number of areas, both technical and humanities because development must be seen in many areas and Chinese government takes into account this fact. All goals are realized in a well thought way via many reforms related to the financing of activities associated with enhancing innovation at universities. The Chinese government has taken action toward the development of China as an innovative nation and it shows that this direction leads to good results.

\section{RESEARCH PROJECTS AT HUST (HUAZHONG UNIVERSITY OF SCIENCE AND TECHNOLOGY)}

Referring to the specific example the HUST has been chosen. This university is one of the best technical universities in China. It is also very well known among universities from developing countries. Thanks to the agreement between RUT (Rzeszow University of Technology) and HUST, it was possible to prepare a lot of information needed to describe the case study of project-oriented universities from China.

At the university, there are provided a lot of projects of different sizes and specification. Over $60 \%$ of all projects are tundertaken, invented and funded by the Chinese government. Approximately $40 \%$ of projects are ordered and funded by companies. In most of projects, students are involved as well as university staff. Young people join to project groups as a personnel and realize a wide scope of tasks.

Very often projects are realized in cooperation with local and national laboratories. There could be mentioned, for example the Wuhan National Laboratory for Optoelectronics (WNLO) which is one of the five national laboratories in China. It has a huge impact on the projects environment at HUST $^{22}$. The other important is Wuhan National High Magnetic Field Center (WHMFC), whose main task is to develop a pulsed high magnetic field facility. Both of these institutions, HUST and about 3 thousand high-tech companies created around the university constitute a very innovative environment for technical and social innovations.

HUST projects can be divided into several levels within the framework of natural science and social science. The Table 1 shows that the total number of approved projects of the National Natural Science Foundation of China in 2006 was 230. In the following years up to 2010 the number of projects was in turn: 258, 342, 374 and 422 . A total in the

\footnotetext{
${ }^{20}$ Own study from Huazhong University of Science and Technology

${ }^{21} \mathrm{http}: / /$ english.hust.edu.cn/about_Facts.html

${ }^{22}$ http://english.hust.edu.cn/Optoelectronics.html?id=1
} 
area were 1626 approved projects from 2006 till 2010. From 2006 to 2010 the cost of the projects amounted to $52.439,8$ million Yuan $^{23}$.

Table 1. National Natural Science Foundation of China

\begin{tabular}{|c|c|c|c|c|c|c|}
\hline Category & $\mathbf{2 0 0 6}$ & $\mathbf{2 0 0 7}$ & $\mathbf{2 0 0 8}$ & $\mathbf{2 0 0 9}$ & $\mathbf{2 0 1 0}$ & Total \\
\hline $\begin{array}{c}\text { The total number of approved } \\
\text { projects }\end{array}$ & 230 & 258 & 342 & 374 & 422 & $\mathbf{1 6 2 6}$ \\
\hline $\begin{array}{c}\text { The number of items face } \\
\text { youth }\end{array}$ & 210 & 244 & 319 & 354 & 402 & $\mathbf{1 5 2 9}$ \\
\hline $\begin{array}{c}\text { Approved project funds } \\
\text { (million Yuan) }\end{array}$ & 6289.2 & 7933.5 & 10613.7 & 12919.5 & 14683.9 & $\mathbf{5 2 4 3 9 . 8}$ \\
\hline $\begin{array}{c}\text { Plane project funds (million } \\
\text { Yuan) }\end{array}$ & 5212.3 & 6021 & 8257.7 & 9425.5 & 8054.5 & $\mathbf{3 6 9 7 1}$ \\
\hline Focus on the number of items & 3 & 3 & 6 & 8 & 8 & $\mathbf{2 8}$ \\
\hline $\begin{array}{c}\text { General Program funds } \\
\text { national rankings }\end{array}$ & 6 & 5 & 5 & 5 & 6 & $\mathbf{2 7}$ \\
\hline
\end{tabular}

Source: Own study based on the scientific report from Huazhong University of Science and Technology, 2014

At the level of National Philosophy and Social Science Fund Program showed in the Table 2, major projects over the years was in 2006: 1, 2007: 2, 2008: 1. In next two years there was not large projects in this area. In the group of general project the amount is bigger. The total number of general projects is 41 , what shows that in the area of National Social and Scientific Fund Program, general projects constitute the majority.

Table 2. National Philosophy and Social Science Foundation

\begin{tabular}{|c|c|c|c|c|c|c|}
\hline & $\begin{array}{c}\text { Major } \\
\text { Projects }\end{array}$ & $\begin{array}{c}\text { Key } \\
\text { Projects }\end{array}$ & $\begin{array}{c}\text { General } \\
\text { Projects }\end{array}$ & $\begin{array}{c}\text { Youth } \\
\text { Projects }\end{array}$ & $\begin{array}{c}\text { Projects } \\
\text { financed with a } \\
\text { delay }\end{array}$ & Total \\
\hline $\mathbf{2 0 0 6}$ & 1 & & 9 & 1 & & 11 \\
\hline $\mathbf{2 0 0 7}$ & 2 & 1 & 4 & 2 & & 9 \\
\hline $\mathbf{2 0 0 8}$ & 1 & & 11 & 3 & & 15 \\
\hline $\mathbf{2 0 0 9}$ & & & 9 & 2 & & 11 \\
\hline $\mathbf{2 0 1 0}$ & & & 8 & 9 & 1 & 18 \\
\hline Total & 4 & 1 & 41 & 17 & 1 & 64 \\
\hline
\end{tabular}

Source: Own study based on the report from Huazhong University of Science and Technology, 2014

The costs of the project are a very important aspect. Universities in China because of the many projects, need to adjust the corresponding costs. The Chinese government funds more than $20 \%$ of the R \& D funds and around $60 \%$ of university research funds come from the government.

The government requires the legitimacy of the business, and expects that the money that was transferred to the investment will be used properly. The costs can be divided according to the type of projects that will be implemented. In the Chart 1, there are annual funding projects in the area of science and technology of HUST from 2001 to 2011. The amount of funds increases each year.

\footnotetext{
${ }^{23}$ Scientific report Huazhong University of Science and Technology, 2014
} 


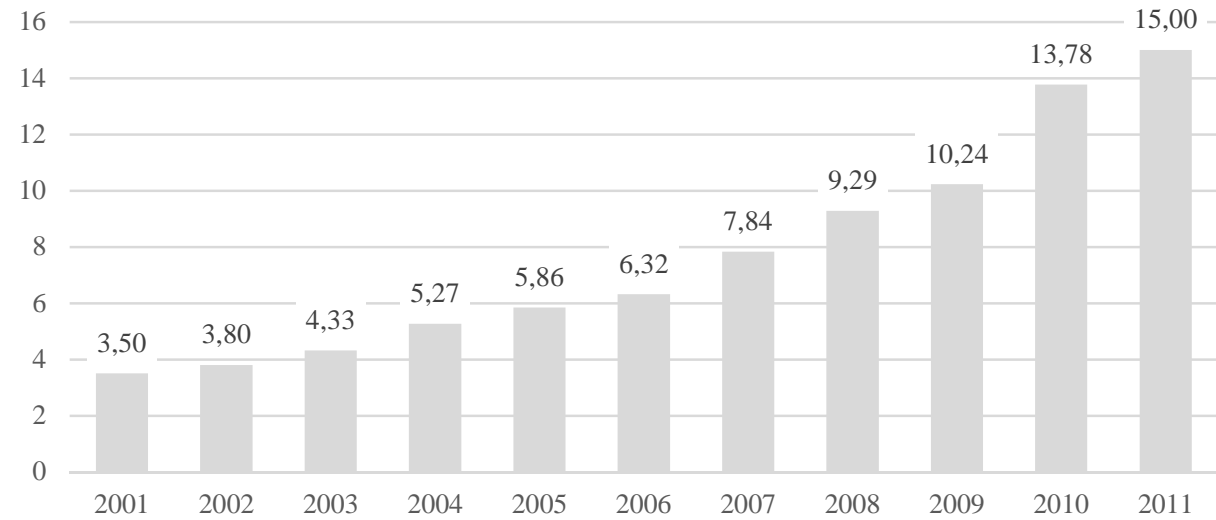

Chart 1. The statistics of the annual funding of science and technology of HUST in billions Yuan Source: Own study based on the report from Huazhong University of Science and Technology, 2014

In the Chart 2, there are annual funding from the National Natural Science Foundation of HUST from 2000 till 2013. The chart shows that the number of projects increases slowly from 2000 till 2013. However, the amount of funds increases rapidly from 2011 till 2013.

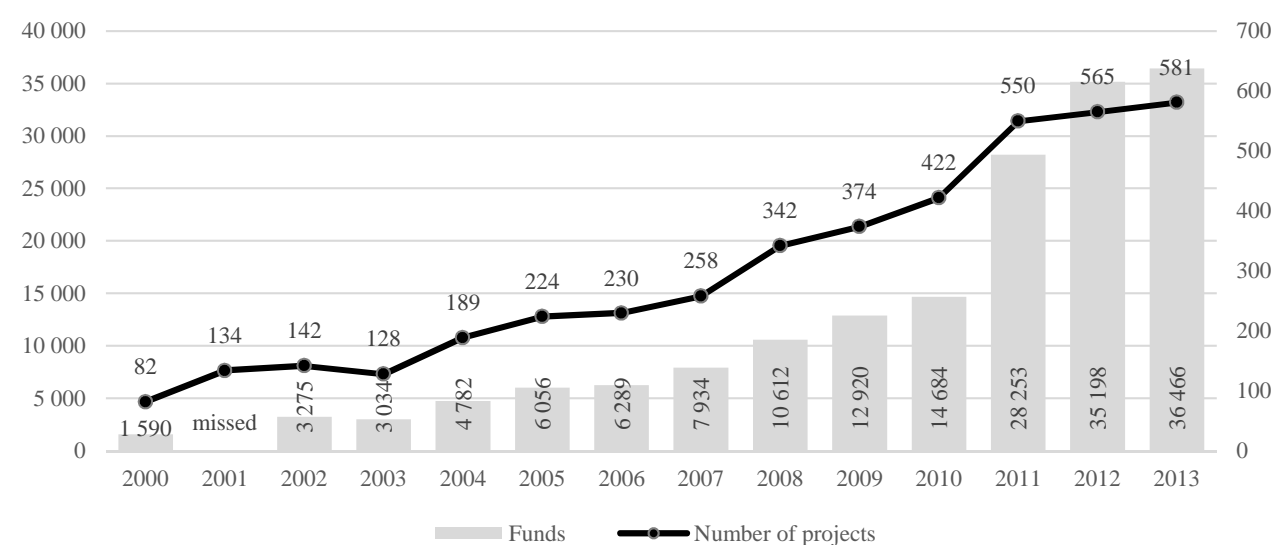

Chart 2. The statistics of the annual funding from National Natural Science Foundation of HUST in million Yuan

Source: Own study based on the report from Huazhong University of Science and Technology, 2014

Data tables showing the quantity and costs of programs confirm that Chinese universities have to deal with highly complex projects. China creates many programs that are aimed at development of education in a wide range. The cost of the projects is large but this is the basis for development.

\section{COMPARISON TO THE GLOBAL APPROACHES}

Project-oriented universities should use one of many methodologies of project management. They indicate and describe ways of conducting projects in an appropriate way. 
Over the years, the methods have developed, adapting to changing conditions of the global environment and new opportunities of competing. Due to the development of projects in various areas, it was noted that it is possible to organize the project in a one structural process $^{24}$. This method made it possible to increase the efficiency of managing the project. The main tool to achieve this effect is project lifecycle ${ }^{25}$. It describes phases of the projects, management techniques, documents, procedures, etc. Each phase should logically correspond to the others. Every single phase ends by milestone, which allows to start the next phase of the project. In a milestone the decision is made whether to continue or terminate the project ${ }^{26}$. It is based on a deep analysis of the project situation. The deviations are measured, assessed and the correction of the plan is made on the basis of this information. All activities connected with the realization of project phases could be undertaken as a Project Lifecycle Model. The description of it is the main part of each methodology.

The most popular methodologies for project management in Europe are PRINCE2 ${ }^{27}$, IPMA $^{28}$ and PMI ${ }^{29}$. Project management is an approach whose geneses started with the Manhattan Project (project of developing a nuclear bomb). This was the time of World War $\mathrm{II}^{30}$. At the end 60 . of the twentieth century, this method was used in companies. At this time two main approaches to project management were created. They were: PMI - Project Management Institute in the USA and IPMA - International Project Management Association, in continental Europe (Austria, Germany) ${ }^{31}$. The PRINC2 methodology was implemented later. It has existed since 1996. It was transformed with a methodology called PRINCE, created in 1989. The methodology is based on the experience of project managers, mainly from the United Kingdom and Anglosphere. This is a project management methodology that is based on products. This approach is used for many projects, especially in public institutions, big organizations and universities as well. This approach consists of principles, themes and processes. Around these elements is the environment.

All of them, but especially the PMI methodology are also used in China. Projects realized at Chinese universities can be compared to the European models of the management process. One of the methodologies having similarities is the methodology of PRINCE2. Similarities among others, to Chinese is the method of financing projects. Many projects in Poland are financed from EU or national funds. In the case of Chinese universities, the Chinese government funds more than $90 \%$ of the projects which are implemented by each university. Money is the amount of data that must be calculated in advance. The same is true in the case of projects funded by the European Union. The

${ }^{24}$ J. Westland, The Project Management Life Cycle: A Complete Step-by-step Methodology for Initiating, Planning, Executing \& Closing a Project Successfully, Kogan Page, 2006.

${ }^{25}$ Ibidem, p. 8.

${ }^{26}$ J. Charvat, Project Management Methodologies, NJ 2003.

${ }^{27}$ OGC, op. cit.

${ }^{28}$ (IPMA) International Project Management Association, IPMA Organizational Competence Baseline - The standard for moving organizations forward, IPMA, Zurich, 2013.

${ }^{29}$ (PMI) Project Management Institute, A Guide to the Project Management Body of Knowledge (PMBOK® Guide), 5th Edition, PMI, Pennsylvania 2013).

${ }^{30}$ T. Seymour, S. Hussein, The History of Project Management, International Journal of Management \& Information Systems, 18(4), 2013, pp. 233-240.

${ }^{31}$ Y.H. Kwak, A brief history of Project Management, [in:] G. Carayannis, Y.H. Kwak, FT. Anbari ed. The story of managing projects, Quorum Books, USA, 2003. 
differences are, however, from the standpoint of nomenclature. In each project, otherwise they are called individuals who are involved in the project.

Table 3. Management methodologies and Chinese universities

\begin{tabular}{|l|c|}
\hline \multicolumn{1}{|c|}{ Scopes of project management } & YES/ NO \\
\hline Named roles in the project & NO \\
\hline Business Justification & YES \\
\hline Steering Committee & NO \\
\hline Project Management Office & NO \\
\hline Stakeholders taken into consideration & YES \\
\hline Project manager position & YES \\
\hline Work Breakdown Structure & YES \\
\hline
\end{tabular}

Source: Own study

PRINCE 2 methodology also shows the role of people in the project and their responsibilities. Moreover, the methodology has a Steering Committee, which decides about major strategic issues in the project. The Steering Committee also acts as a liaison between the management team and all external stakeholders. The Steering Committee approves all important decisions which lowers the final responsibility of the project manager. At the head of the steering committee is a chairman who makes the final decision. What is more, from the point of view of the project Steering Committee is very important because the project manager is controlled by a few people who check its performance in different areas. $^{32}$

Universities in China should create a Steering Committee in their projects because this type of solution offers the possibility of greater efficiency of project implementation, better control of the project manager and facilitate enforcement of responsibility for work in the project. Establishing roles in the project are also a way for better communication management, especially during difficult periods of the project. This type of structure facilitates decision-making, problem solving, delegation of members of the project / team to tasks. Furthermore, China does not have enough managers and staffs due to wrong human resource policies because that most of the universities and research institutes are public ones and the human resources are strictly controlled by the government.

\section{CONCLUSIONS}

The analysis presented in this paper is not exhaustive. The points in the article are very important and interesting in the area of further research. Universities in China are different comparing to institutions of higher education in Europe. To understand them it is necessary to combine both historical and cultural aspects, which are an integral part of education in China. Over the years, the standards of education and research have changed. It results that some universities are at the forefront of the world rankings.

The information being provided by universities shows approaches to project management. This article aimed at analyzing the similarities between the way of creating projects at Chinese universities in comparison to methodologies known in Poland and Europe. In the structure of the projects there are many similarities to European but also the shortcomings that should be changed to greater efficiency. First of all in projects there should be clearly defined roles assigned to the specific tasks and responsibilities. Very

\footnotetext{
${ }^{32}$ Ibidem, p. 8
} 
important is also an implementation of the Steering Committees and Project Management Offices. They ensure the supervision and coordination of the project and portfolio of projects.

\section{REFERENCES}

[1] (IPMA) International Project Management Association, IPMA Organizational Competence Baseline - The standard for moving organizations forward, IPMA, Zurich, 2013.

[2] (OGC) Office of Government Commerce, Managing Successful Projects with PRINCE2 ${ }^{T M}$, TSO, London 2009.

[3] (PMI) Project Management Institute, A Guide to the Project Management Body of Knowledge (PMBOK® Guide), 5th Edition, PMI, Pennsylvania 2013).

[4] A Guide to the Project Management Body of Knowledge (PMBOK GUIDE) Fourth Edition, PMI Project Management Institute, Global STANDARD.

[5] Andersen E.S., Jessen S.A., Project maturity in organisations, International Journal of Project Management, 21.6, 2003, 457-461.

[6] Bakouros Y.s, Vassilis K, Project Management, ., Report produced for the EC funded project, January 2000.

[7] Binder J. , Global Project Management: Communication, Collaboration and Management across Borders, Emerald Group Publishing Limited.

[8] Busch R., McMahon R., Unger A., May Ch., Ya-Cheng Wang, A Comparison of Leadership Styles between Chinese and German Managers of Chinese Companies in Germany, Web Journal of Chinese Management Review.

[9] Chapman Ch. and Ward St. (1996) Project risk management: processes, techniques and insights, Chichester, UK, John Wiley.

[10] Charvat J. Project Management Methodologies, NJ, 2003.

[11] Court R., An Introduction to the PRINCE2 project methodology, CIMA, 42006.

[12] Ennew Ch. and Fujia Y., Foreign Universities in China: a case study, European Journal of Education, Vol. 44, No. 1, 2009, Part I;

[13] Fuessinger E., Maturities of Project-Oriented Companies of About 15 Project-Oriented Nations, 2006 [online] Avaliable at: 〈http:// www.icoste.org/Slovenia2006 Papers/icecFinal00100.pdf> [Accessed 26 July 2015].

[14] Gareis R., Happy Projects!, Manz, Vienna 2005.

[15] Goodall K., Li, N., and Warner, M, Expatriate managers in China: the influence of Chinese culture on cross-cultural management, Cambridge Judge Business School,

[16] Hayhoe, R. . China's Universities and the Open Door. Armonk, N.Y.: M.E. Sharpe, 1989. xii, 249.

[17] http://english.hust.edu.cn/about_Facts.html

[18] http://english.hust.edu.cn/Optoelectronics.html?id=1

[19] http://english.hust.edu.cn/Optoelectronics.html?id=6

[20] http://news.nost.org.cn/2013/06/new-education-plan-10-billion-rmb-investment-in-100-localuniversities-in-midwest-china/

[21] http://news.xinhuanet.com/2014-10/23/c_1112948665.htm

[22] http://www.973.gov.cn/English/Index.asp

[23] International Competence Baseline (ICB), International Project Management Association.

[24] Kerzner H., Using the project management maturity model: strategic planning for project management, John Wiley \& Sons, Ohio 2011.

[25] Kwak Y.H., A brief history of Project Management, [in:] G. Carayannis, Y.H. Kwak, FT. Anbari ed. The story of managing projects, Quorum Books, USA, 2003.

[26] Lianyinga L., Jinga H., Xinxinga Z., The Project Management Maturity Model and Application Based on PRINCE2, Procedia Engineering, 29, 2012, 3691-3697.

[27] Munns A.K., Bjeirmi B.F., The role of project management in achieving project success, International Journal of Project Management, 14(2), 1996, 81-87. 
[28] PRINCE2 - Skuteczne Zarzadzanie Projektami, 2009, AXELOS.

[29] Rarick Charl A., Ph.D., Confucius on Management: Understanding Chinese Cultural Values and Managerial Practices, Journal of International Management Studies, August 2007.

[30] Scientific report Huazhong University of Science and Technology.

[31] Strojny J., Kompleksowe podejście do zarzadzania projektami na przyktadzie uczelni wyższej [A comprehensive approach to project management on the example of university] Wydawnictwo SAN, zeszyt 12, część I, ss. 247-262.

[32] Strojny J., Kultura projektowa - parametry oceny i wpływ na przebieg projektów, Humanities and Social Sciences, vol. XVIII, 20 (1/2013), pp. 105-116, January - March, 2013.

[33] Strojny J., Zarzadzanie projektami innowacyjnymi, Rzeszów, Politechnika Rzeszowska, 2012.

[34] T. Seymour, S. Hussein, The History of Project Management, International Journal of Management \& Information Systems, 18(4), 2013, 233-240.

[35] Westland J. The Project Management Life Cycle: A Complete Step-by-step Methodology for Initiating, Planning, Executing \& Closing a Project Successfully, Kogan Page, 2006.

[36] Wiley J. \& Sons Ltd, Chichester Project Management: Planning and Control Techniques Rory Burke Third Edition, , England 1999.

[37] Zhou J., Minister of the Ministry of Education. Higher Education in China. Cengage Learning; 1st edition (July 30, 2005).

\section{WYBRANE ASPEKTY REALIZACJI PROJEKTÓW W CHIŃSKICH UNIWERSYTETACH NA PRZYKLADZIE HUAZHONG UNIVERSITY OF SCIENCE AND TECHNOLOGY (HUST)}

Współcześnie zarządzanie projektem jest fundamentem rozwoju różnych organizacji w zmieniającym się, globalnym środowisku. Metoda ta jest bardzo popularna w rozwiniętych krajach europejskich, a w Polsce popularność zyskuje na przestrzeni ostatnich 10 lat. W innych krajach rozwijających się na świecie, projekty stają się również bardzo ważną częścią gospodarki. Ta sytuacja ma miejsce między innymi w Chinach.

Celem artykułu jest analiza chińskich uniwersytetów, na przykładzie HUST (Huazhong University of Science and Technology), w kontekście systemu zarządzania projektami oraz porównanie podejść tam stosowanych do najbardziej popularnych metod w krajach europejskich. Obecnie Chiny wyróżniają się w świecie w zakresie reform realizowanych w obszarze systemów szkolnictwa wyższego i innowacji. Wielkość inwestycji i uzyskanych efektów ekonomicznych stawia ten kraj w czołówce na świecie w tej dziedzinie. Tym ważniejsze jest podejmowanie prób wyjaśnienia i zrozumienia zjawisk zachodzących w tym kraju.

Chińskie uniwersytety często realizują bardzo duże projekty, co wynika zarówno z wielkości państwa, jak i ilości mieszkańców. Analizując sytuację na podstawie HUST widać było wykorzystanie metod zarządzania projektami, podobnych do Unii Europejskiej. Istnieją również różnice wynikające z kultury zarządzania projektami.

Artykuł oparty jest na badaniach i informacji zebranych w chińskich uniwersytetów, zwłaszcza HUST. Wiedza i zdobyte informacje pozwoliły na opisanie roli projektów w badanej uczelni i ogólnie porównać.

Słowa kluczowe: zarządzanie projektami, Chiny, chińskie uczelnie, uniwersytet.

\section{DOI: 10.7862/rz.2015.mmr.24}

Tekst złożono w redakcji: sierpień 2015

Przyjęto do druku: sierpień 2015 